\title{
Addressing the Educational Challenges of Experiential Learning in Teaching of Internet Marketing at Thompson Rivers University
}

\author{
By Andrew Idzikowski*
}

\begin{abstract}
One of many educational challenges in higher education is to combine theory with the practical knowledge that students need to have learned upon graduation. Most business schools in North America address this issue by using case studies. In the business area of internet marketing, learning by analyzing case studies does not create the excitement in students that many teachers would hope for. Unless the learning objectives are directly linked to the students' personal career objectives, the success of the traditional case study approach is slowly decreasing. To break from a typical case study approach, this Author has introduced a modified live case study to the students in the School of Business at Thompson Rivers University (TRU) in Canada. Instead of collaborating with external businesses sponsors, the students became project sponsors themselves. The entire experience required the marketing students to obtain the knowledge needed to fully understand many challenges of internet marketing. It included real activities such as developing content for a website, creating and running online advertising, monitoring website performance, and solving many challenging problems.This paper summarizes this live case study experience, which has been successfully implemented in the last two semesters at TRU. It provides recommendations that other instructors may consider before introducing a similar experience in their classrooms.
\end{abstract}

\section{Introduction}

The proliferation of Internet technologies into many facets of business activities has put a lot of pressure on higher education throughout the world. Today's students are expected to obtain the traditional business knowledge of the past as well as to become technological leaders of the future. We can find many examples of successful university graduates becoming entrepreneurs in a relatively short time, for example Chad Hurley, Steve Chen, and Jawed Karim, who have founded YouTube (Hopkins 2006). Since the invention of the Internet, combining an increasing amount of theoretical knowledge with practical skills within a typical four-year bachelor degree business programs has created more challenges for educators. At the same time, a general

"Lecturer, School of Business and Economic, Thompson Rivers University, Canada. 
expectation of instant business success upon graduation also has introduced another dimension to the entire business education. Some of these issues, for example, the impact of technology on society, have been explored on a global scale by Butler (2012) and Chmielecki (2013). Combining two factors such as theory and practice became more challenging when applied to business areas such as internet marketing. This particular business activity is further driven by the ever-evolving Internet technology. Most business schools in North America address this issue by using case studies. Many authors argue that this approach to teaching in higher education meets the Kolb's experiential model and can be an effective way to provide the students with the necessary practical learning experience. Other authors argue that traditional case studies themselves cannot replace learning without real live experience. The traditional case studies, also called theoretical case studies, don't have enough of a practical component compared to learning by doing (McCarthy 2006). This paper focuses on the implementation of a live case study by this Author for teaching internet marketing as it has been introduced in the School of Business and Economics at Thompson Rivers University.

\section{Experiential Learning Methods}

In the business area of Internet Marketing, learning by analyzing traditional case studies is a common pedagogical method. Linking theory with practice in those case studies is by far more effective than just following textbook examples and memorizing conceptual models (Ward and Rudelius 1987). The traditional case studies provide the student with a written description of a business scenario and a series of tasks or questions that the students need to complete. Some of the many problems of these case studies are that they are impersonal and often unrealistic. Furthermore, the students may be more creative and may develop better solutions than the expected ones in the attached answer key. It is then up to the instructor to fairly evaluate the submitted solution.

The traditional case study approach can further be enhanced by giving the students a live case study in which they experience a specific actual business problem. This method has been recently described by McHann and Frost (2010) and is called a living case study.

The main difference between the traditional case studies and the live case studies is that the students, instead of working with a hypothetical business scenario, work with a real company (often called project sponsor). As a result, the students are exposed to real business problems, real products, real marketing campaigns and, occasionally, real failures. There are several major benefits of this approach: it provides higher motivation for students, increases students' learning experience beyond the subject area (e.g. team work experience), it provides a sense of achievement, and it provides a strong motivation for learning. 


\section{Introducing a Live Case Study to Internet Marketing Students}

From the Author's personal teaching experience at Thompson Rivers University (TRU) in Canada, traditional case studies do not create the excitement in students that many instructors would hope for. Unless the learning objectives are directly linked to the students' personal career objectives, the success of the traditional case studies approach is slowly eroding. Considering several alternatives to traditional case studies, this Author has introduced a modified live case study. The modified version places the students in the role of a project sponsor.

A revised version of the Live Case Study Participants' Benefits and Costs analysis, as presented by Burns (1990), has been created for the purpose of evaluating the feasibility of the modified live case study. The main objective of the following table is to evaluate the potential risks of exceeding the students' willingness to engage in such a complex project.

Table 1. A Modified Live Case Study Participants'Benefits and Costs

\begin{tabular}{|c|c|c|}
\hline Participant & Benefits & Challenges \\
\hline \multirow{7}{*}{$\begin{array}{l}\text { Student/ } \\
\text { Business } \\
\text { Partner } \\
\text { (Project } \\
\text { Sponsor) }\end{array}$} & $\begin{array}{l}\text { Real-world experience with } \\
\text { internet marketing } \\
\text { environment }\end{array}$ & $\begin{array}{l}\text { Frustration from low skills or } \\
\text { ability to complete the work }\end{array}$ \\
\hline & Self-confidence & Time requirements \\
\hline & $\begin{array}{l}\text { Enhanced entrepreneurial } \\
\text { skills }\end{array}$ & $\begin{array}{l}\text { Unable to oversee the entire } \\
\text { project }\end{array}$ \\
\hline & $\begin{array}{l}\text { Enhanced technological } \\
\text { skills }\end{array}$ & Steep learning curve \\
\hline & Web development experience & \multirow{3}{*}{$\begin{array}{c}\text { Funding of web hosting and } \\
\text { advertising }\end{array}$} \\
\hline & $\begin{array}{c}\text { Exposure to potential } \\
\text { employers }\end{array}$ & \\
\hline & $\begin{array}{l}\text { Potential success as a result } \\
\text { of creating a unique business }\end{array}$ & \\
\hline \multirow[b]{2}{*}{ Instructor } & $\begin{array}{c}\text { Provides meaningful } \\
\text { education }\end{array}$ & $\begin{array}{c}\text { Increased complexity of } \\
\text { assessment }\end{array}$ \\
\hline & $\begin{array}{l}\text { Increases personal practical } \\
\text { knowledge }\end{array}$ & $\begin{array}{l}\text { Dealing with unexpected } \\
\text { issues that need immediate } \\
\text { solutions }\end{array}$ \\
\hline
\end{tabular}

In order to try this new live case study method, the Dean of School of Business and Economics at TRU has provided a grant to cover the cost of web hosting for approximately 80 students. This grant has eliminated the potential of wasting students' funds in the case of a project's failure. The grant has also allowed for some "trial and error" experimentation with web hosting before selecting one that could be funded by the students themselves in future semesters. Since students in Canada already pay tuition fees to enroll in university courses, providing a free case study environment has increased their 
engagement and willingness to participate. After the initial experimental phase, students themselves would provide the funds to cover the additional expenses in the course.

\section{Multi-Phased Live Case Study at TRU}

The live case study (called the project), as introduced to the marketing students, involved the development of websites by teams of two students. The project was included in the E-Commerce course offered to students in the fourth year of the Bachelor of Business Administration program at TRU. The entire development process began with the creation of a business idea followed by the creation of a website in WordPress, then moved to advertising on the Google Search Network, and ended with web traffic monitoring in Google Analytics. The entire process covered all practical skills that marketing students need to obtain as typically expected by employers.

\section{Internet Marketing Learning Objectives}

The project's objectives were aligned with the principal internet marketing learning objectives outlined by many authors such as Roberts (2008), Chaffey (2012), or Strauss and Frost (2012). Table 2 summarizes major topics together with their corresponding learning objectives included in the project.

Table 2. Internet Marketing Topics and Objectives Included in the Project

\begin{tabular}{|c|c|}
\hline Topic & Learning Objective \\
\hline \multirow{2}{*}{$\begin{array}{l}\text { Online Brand } \\
\text { Development }\end{array}$} & Explain how to develop an online brand \\
\hline & Design and register a domain name \\
\hline \multirow{3}{*}{$\begin{array}{l}\text { Legal and Privacy } \\
\text { Issues }\end{array}$} & Develop terms of use statement for a website \\
\hline & $\begin{array}{l}\text { Identify major issues of online privacy and develop a privacy } \\
\text { statement for a website }\end{array}$ \\
\hline & Protect the privacy of visitors to a website \\
\hline \multirow{6}{*}{$\begin{array}{l}\text { Developing and } \\
\text { Maintaining } \\
\text { Effective Websites }\end{array}$} & Explain each step in a website development process \\
\hline & Identify and resolve important web design issues \\
\hline & Design and develop a website with common development tools \\
\hline & $\begin{array}{l}\text { Explain and apply the concepts of usability and customer } \\
\text { experience as applied to websites }\end{array}$ \\
\hline & $\begin{array}{l}\text { Maintain a website in a typical business hosting environment } \\
\text { ("paid" hosting) }\end{array}$ \\
\hline & Identify and implement Search Engine Optimization techniques \\
\hline \multirow[b]{2}{*}{$\begin{array}{l}\text { Internet } \\
\text { Advertising }\end{array}$} & Develop and implement a simple PPC advertising campaign \\
\hline & $\begin{array}{l}\text { Analyze and improve effectiveness of a PPC advertising } \\
\text { campaign }\end{array}$ \\
\hline \multirow{4}{*}{$\begin{array}{c}\text { Measuring and } \\
\text { Evaluating Web } \\
\text { Traffic }\end{array}$} & $\begin{array}{l}\text { Describe and use techniques to monitor a website's } \\
\text { performance }\end{array}$ \\
\hline & Identify sources of traffic to a website \\
\hline & Calculate costs involved in bringing traffic to a website \\
\hline & Improve effectiveness of internet advertising \\
\hline
\end{tabular}




\section{The Four Stages of the Project}

The entire project has been divided into the following four stages (see Figure 1 below): (1) Development of a business idea (2) Development of a website (3) Building traffic to the website (4) Measuring the effectiveness of the website. Each stage has introduced a specific difficulty and addressed a variety of different learning objectives.

Figure 1. The Four Stages of Project Development

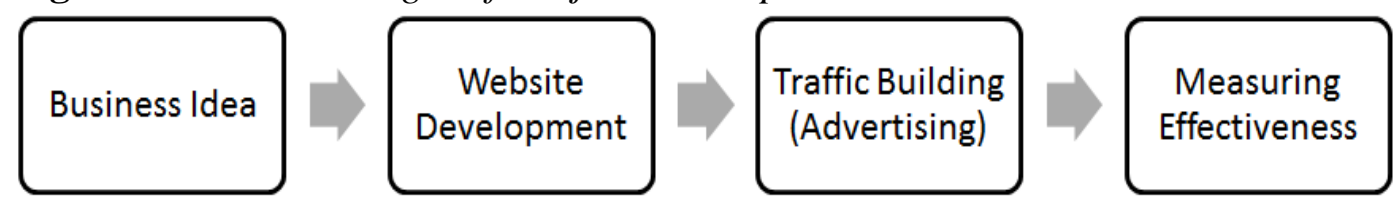

In the first stage, the students were required to develop an idea for an online business or web presence. This step provided an opportunity to formalize some of the initiatives that many business students already had, but had never had time to evaluate. Deliverables produced as a result of this phase included a document that described the idea, a simplified market analysis, a SWOT analysis, and a brief evaluation of direct competitors.

The second stage proved to be the most time consuming and frustrating to the students. Developing a website without prior experience required a lot of commitment because the students were not familiar with the commercial hosting environment and web building tools such as WordPress. Although creating websites with WordPress does not require prior computer programming experience, without the students' practical knowledge of Microsoft Office tools such as PowerPoint, Word, Excel, and Access, the website development would have not been possible. The required website content included the following pages: Home, About Us, Contact Us, Privacy Statement, Terms of Use, and three subject specific content pages. An important note has to be made that at this time of the course, legal and privacy issues as well as website design principles had already been discussed. The students by then had the necessary theoretical knowledge needed to start creating a website.

The third stage was the least frustrating to the students. They were required to create a Google AdWords account and develop an advertising campaign to attract visitors to their website. Instead of promoting other websites, the students worked on promoting their own websites. As a result, their engagement throughout the entire learning experience in this stage of the project showed the highest level of involvement. Using Google advertising environment did not create any major challenges, and most students were able to complete their tasks on time. Although advertising campaigns were limited only to Google Search Network, the entire learning experience provided the students with the skills essential to internet marketing. Unfortunately, PPC advertising is not free, and the students were required to cover their own costs 
of advertising. Running active campaigns was limited to one week with the maximum daily budgets of $\$ 5$ or less.

The last stage of the project involved learning how to monitor traffic to a website. The students were required to link their AdWords accounts with the Google Analytics account created at this point of the project. This link enabled them to identify and evaluate different sources of web traffic. Introducing this particular learning experience provided a more meaningful background for a class discussion about advertising campaigns and for the improvement of visitors' engagement. Terms such as unique visitor, bounce rate, or page views required no additional explanation in the classroom.

\section{The Challenges of the Project}

The entire project has created several challenges for the students as well as this Author. The most difficult aspect of this project was to keep each stage aligned with the theoretical topics covered in the classroom throughout the entire 13-week semester. This was essential as the students needed to obtain specific knowledge before starting each stage. The project necessitated a great deal of additional learning by discovery as students explored unfamiliar features with only minimal support in the classroom. This lack of support revealed itself in a frustration that students have not experienced in other courses. In future semesters, it would be beneficial to break the website development stage into two or three additional phases that would make the tasks more manageable. On the other hand, introducing the students to a real web hosting environment created a real live experience that would have not been otherwise possible. A third challenge of live case studies approach to learning with case studies is that they can be introduced only in upper level courses.

\section{A Summary of Students' Works}

The majority of students implemented their primary business ideas outlined in the first stage of the project. Most of them, however, were unable to fully implement their initial ideas as they found this too difficult, but it was not detrimental to the students' experience as it was not expected for them to deliver the entire business idea. It became clearly visible to them how difficult the implementation of an idea is. There were several categories of ideas selected by the students for their projects. The most popular were review websites for a variety of different subjects $(32 \%)$. Other popular websites were sponsorship sites promoting local businesses (16\%), followed by clothing ecommerce $(13 \%)$, and physical training guides $(8 \%)$. All of these websites were developed in WordPress hosted on www.landl.ca.

The students were particularly engaged in the project when given an opportunity to start advertising with Google AdWords. This opportunity was possible after their websites already had been built. The students developed their own AdWords advertising campaigns and linked them later to Google Analytics. Normally, such internet environments are not accessible to students because they contain confidential business information. This practical 
experience enhanced understanding of online marketing tools and website development strategies as identified in the course learning objectives. These activities were highly motivational to students; however, the costs of advertising had to be closely monitored. The majority of students have not exceeded the Author's \$25 limit for all costs of AdWords advertising.

\section{Students'Accomplishments}

The students' accomplishments can be directly related to the project environment as depicted in Figure 2. It shows how complex this environment was for students. For a business student, this environment was overwhelming at first, but it became manageable by the end of the semester. The students have developed a great sense of confidence and achievement after completing tasks outlined for each stage.

Figure 2. Project Environment used by the Students

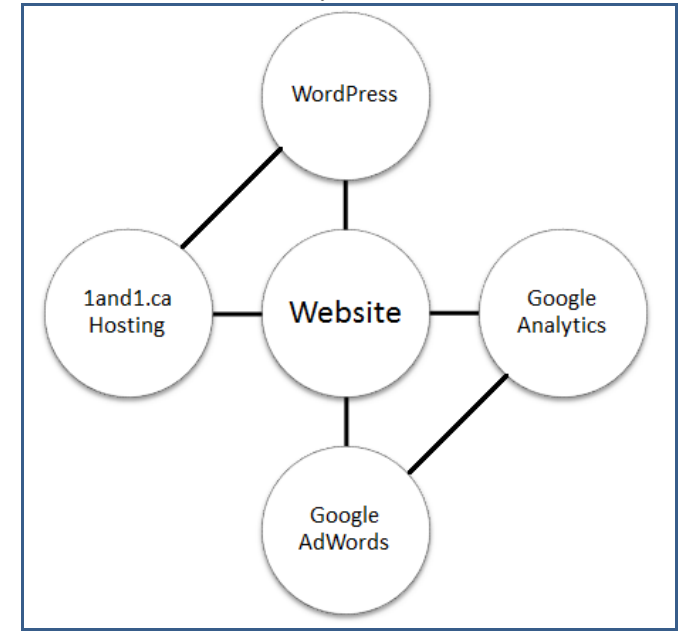

The feedback received from the students included comments such as "Overall, this has been an exciting project that will benefit our future." or "I really enjoyed this project. It was a great 'hands on' learning tool. I believe it is something valuable that I can take with me and use again in my career" (TRU Students, personal communication, March 25, 2014).

\section{Advantages and Disadvantages of a Life Case Study}

As business activities have already moved to the Internet, providing business students with live Internet projects is a natural progression in higher education. An issue then arises whether to use a live case study involving real businesses or engaging students in their own entrepreneurial initiatives. There are several legal issues to both approaches. In live case studies in collaboration with businesses, the issue is security. Students could breach security by accidentally releasing confidential information to the public. To avoid such 
disclosure, students are given a mock version of business resources. In these cases, however, students do not have access to Google AdWords advertising, a significant limitation on the experience. So an alternative solution is a live case project that replaces business partners with the students, themselves, in that role. Students are in control of the entire learning experience and learn directly from their own mistakes. They are also motivated to develop skills needed to shape their own independent business careers. One disadvantage, thought, is that the internet environment presented in Figure 2 is very complex and students require strong technical support provided by the supervising instructor. It is essential that this support is readily available to students. This is a major disadvantage of specific live case studies. In spite of this, the live case study, as described in this paper, has provided the students with invaluable practical experience that can only be accomplished live on the Internet.

\section{Recommendations}

Starting a live case study, which involves creating real websites and online advertising, demands special considerations. It would be beneficial to introduce it as a pilot project. It would put less pressure on the students as their grades would be less dependent on the outcomes of the project. There are several considerations that need to be evaluated. They are described in the following sections.

\section{Selecting the Right Web Hosting Environments}

One of the most critical issues for this project is the selection of the most appropriate web hosting environment. In the Author's pilot project, the students were given access to the web hosting environment provided by a Canadian company. The cost of web hosting was prepaid by a decanal grant from the School of Business and Economics at TRU. This environment provided the students with all the necessary tools, but its web interface was difficult to use. In the second year, after the pilot project was complete, the students were requested to use a different web hosting environment. The new web hosting environment (1and1.ca) provided the students with a better webbased interface, but it required more computer knowledge in order to use it. Overall, the second web hosting proved to be more user-friendly and more likely will be selected for the future projects. The Author deliberately chose to use a paid web hosting (\$60/year) as opposed to free web hosting. Free web hosting does not provide the full set of options and is limited to predefined solutions. Furthermore, a fee is charged for additional features. Eventually, adding those fees would add up to an amount equivalent to the paid hosting. Unlike free hosting, both paid web hosting companies selected for the projects included a full complement of features and extensive user support. It is also recommended to use WordPress for building websites. WordPress script has strong support on the Web, and it does not require a steep learning curve. WordPress comes with a large base of additional "plug-ins" that provide a 
variety of common features often used on websites. Also, contrary to free hosting, a paid hosting environment is by far more complex. It resembles the environment in which business graduates will likely be involved in the future. It provides challenges and personal opportunities as students could pursue their individual initiatives.

It is also strongly recommended that the course instructor run a parallel project in the same environment as the students' environment. This project, which resembles the students' projects, would simplify preparation of necessary lectures as the project progresses through the development stages.

\section{Timing the Projects}

At Thompson Rivers University each semester is 13 weeks long. Timing the project's four stages requires a proper alignment with the course content introduced to the students in classroom lectures. Figure 3 shows the major topics and timing of these topics in a 13 week semester.

Figure 3. Timing the Project in a 13-Week Semester

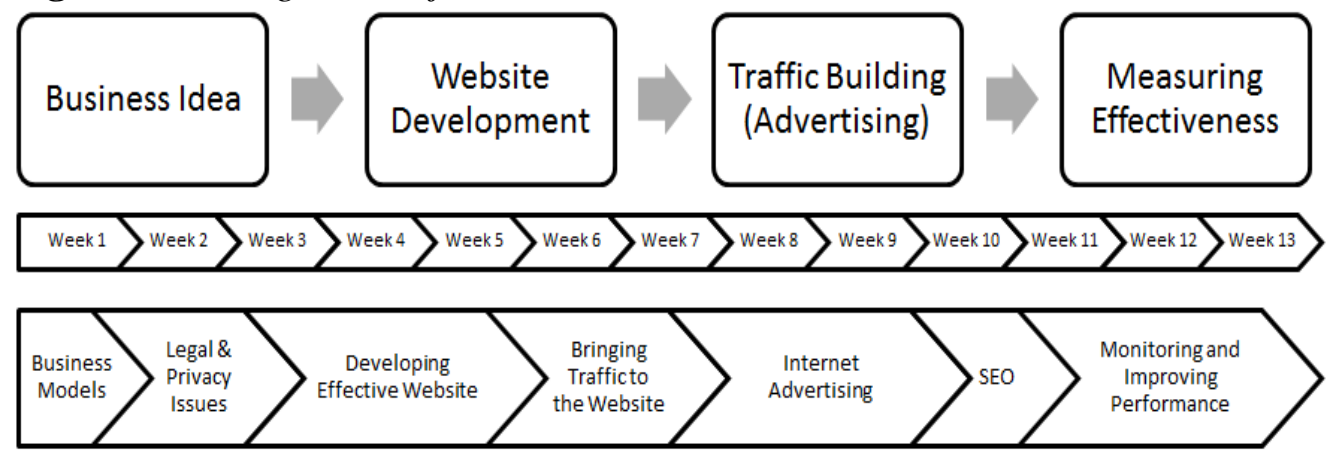

Increasing Internet Advertising Content

In prior semesters, the students were only required to create AdWords advertising campaigns on Google Search Network. AdWords text advertising is simpler because it does not require familiarity with computer graphic tools such as Photoshop. Extending internet advertising to Google Display Network would create additional difficulty and challenges to the overall advertising experience because it would satisfy the need for students to be familiar with the two types of advertising: text and display ads.

\section{Adding a Social Media Presence}

An increasing number of businesses start using social media for the purpose of engaging customers online. Social media are especially well suited to raising brand awareness (Strauss and Frost 2012). They provide another important channel for creating and maintaining brand awareness. According to StatCounter Global Stats (2014), Facebook is the most popular social media site used $54 \%$ of the times, far outstripping the other top 7 social media websites in North America. Extending the project to include a social media presence such as Facebook would involve the students in building their own 
brand awareness. The students could also extend their social media activities to connect to their peers' Facebook accounts, so the entire class could potentially become a virtual community.

\section{Conclusion}

The live case study described in this paper has provided the business students at Thompson Rivers University with the basic practical knowledge needed to understand the challenges of today's internet marketing. It included activities such as developing website content, creating and running online advertising campaigns, monitoring advertising costs and their effectiveness, and monitoring the overall website performance. The students were faced with a challenging and unfamiliar website development environment. Consequently, they had an opportunity to become familiar with WordPress, which enabled them to advertise on Google Search Network, and to use Google Analytics to monitor traffic to their websites. Furthermore, case studies of this complexity that involve external business partners may be found unsuitable for several reasons, the same reasons as stated by Burns (1990) in the pre-Internet world. The project sponsors would have to face very demanding schedules with a possibility of divulging sensitive information to the public or running advertising campaigns that could potentially damage their reputations. Because the students in the project created their own web presence, they had the full freedom to experiment in their own environment. Such a multifaceted environment would not typically be accessible to students when working with external project sponsors.

The overall experience of this live case study can be summarized by a student who said:

"Throughout our years of education, we have both made a number of websites for a variety of university projects. However, this was the first circumstance in which we had to create a website on server space that we have purchased. Though we did not write the HTML code, there were many challenges that we had to overcome in the process of developing this website, allowing us to learn more in depth about running a simple website, adding plug-ins and choosing the right theme". (TRU Student, personal communication, March 9, 2014).

\section{Acknowledgments}

This Author would like to thank Dr. Russell Currie, Dean of School of Business and Economics at Thompson Rivers University, for providing a pilot project funding to introduce the live case study to the students in BBUS 4450 E-Commerce course. 


\section{References}

Bow Burns, A. C. (1990).The Use of Live Case Studies in Business Education: Pros, Cons, and Guidelines. In J. W. Gentry (Ed), Guide to Business Gaming and Experiential Learning (pp.201-215). Association for Business Simulation and Experiential Learning (ABSEL).

Butler, R. P., Draper, D. (2012). Technology Lenses: Ways of Seeing the World. Athens: ATINER'S Conference Paper Series, No:EDU2012-0042.

Chmielecki, P. (2013). Claims of Business Ideology to University Education Athens: ATINER'S Conference Paper Series, No: ECO2013-0796.

Chaffey, D., Ellis-Chadwick, F. (2012). Digital Marketing Strategy, Implementation and Practice, Pearson $5^{\text {th }}$ edition

Hopkins, J. (2006, October 11). Surprise! There's a third YouTube co-founder. USA Today. Retrieved from http://www.usatoday30.usatoday.com

Kreber, C. (2001). Learning Experientially through Case Studies? A Conceptual Analysis. Teaching in Higher Education Volume 6, Issue 2, 217-228.

McCarthy, P., and McCarthy, H. (2006). When case studies are not enough: integrating Experiential Learning into Business Curricula. The Journal of Education for Business, 81(4), 201-204.

Global Stats (n.d.). Top 7 Desktop, Tablet \& Console Social Media Sites from Mar 2013 to Mar 2014. StatCounter. Retrieved from http://gs.statcounter.com/\#social _media-ww-monthly-201303-201403

Strauss, J., Frost, R. (2012). E-marketing, Boston: Pearson Education Internat. $6^{\text {th }}$ Edition. 
